\title{
Migrant pupils' scientific performance: the influence of educational system features of origin and destination countries
}

\author{
Jaap Dronkers ${ }^{*}$, Mark Levels and Manon de Heus
}

\author{
* Correspondence: \\ j.dronkers@maastrichtuniversity.nl \\ Research Centre for Education and \\ the Labour Market $(\mathrm{ROA})$, Maastricht \\ University, P.O. Box 616, 6200, MD \\ Maastricht, The Netherlands
}

\begin{abstract}
Background: Earlier studies using a double perspective (destination \& origin) indicate that several macro-characteristics of both destination and origin countries affect the educational performance of migrant children. This paper explores the extent to which educational system features of destination and origin countries can explain these differences in educational achievement of migrant children, next to these macro-characteristics.
\end{abstract}

Methods: Using data from the 2006 PISA survey, we performed cross-classified multilevel analysis on the science performance of 9.279 15-year-old migrant children, originating from 35 different countries, living in 16 Western countries of destination. We take into account a number of educational system characteristics of the countries of destination and origin, in order to measure the importance of differentiation, standardization, and the availability of resources.

Results: We show that differences in educational achievement between migrants cannot be fully attributed to individual characteristics or macro-characteristics. Educational system characteristics of countries of destination and origin are also meaningful. At the origin level, the length of compulsory education positively influences educational performance. This is especially the case for migrant pupils who attended education in their countries of origin. We show also that at the destination level, a high student-teacher ratio in primary education positively affects migrant pupil's scientific performance. Moreover, migrant children with low educated parents do not perform less in highly stratified systems and even perform better in moderately differentiated systems than they do in comprehensive one. But migrant children with highly educated parents perform worse in highly and moderately stratified systems.

Conclusion: This study underscores the importance of educational system features as an explanation of differences in educational achievement across different origin groups and across migrants living in different destination countries. Although individual level characteristics account for the largest educational achievement differences, educational system characteristics have an effect on top of these individual level characteristics and the average educational performance in their countries of origin. Differences in educational systems contribute to explaining the effects of economic and political macro-characteristics of the countries of origin on the educational performance of migrant children in destination countries.

(Continued on next page)

\section{空


(Continued from previous page)

Keywords: Immigration; Origin; Destination; Educational system; Educational performance; PISA

\section{Background}

A large body of research has shown that the educational success of migrant children varies between different origin groups. Substantive variation exists in educational outcomes of different migrant groups in the United States: Mexican Americans obtain lower average grades than Asians and whites (Bankston and Zhou, 2002; Kao, Tienda, and Schneider, 1996; Miller, 1995), they are more likely to drop out of high school (White and Kaufman, White and Kaufmann 1997), and less likely to earn a college degree (Camburn, 1990; Mare, 1995). Similar gaps in educational success between different migrant groups and the native population have been observed in most other Western countries such as the Netherlands (van Tubergen and van de Werfhorst, 2007), Belgium (Phalet, Deboosere, and Bastiaenssen 2007), Germany (Worbs, 2003), and France (Brinbaum and Cebolla-Boado, 2007). In order to explain these differences, research has often relied on classic individual-level determinants. These individual-level explanations have focused on differences in the cultural position (e.g. their motivation to perform) and the structural characteristics (e.g. parental capital and the time of arrival) of different migrant groups (Kao and Thompson, 2003).

Although individual-level characteristics explain an important part of the variance in educational performance across migrant groups, they do not tell the whole story. After controlling for a wide range of individual background characteristics (e.g. the educational attainment and occupational status of both parents, educational resources available at home, the migrant generation, and the language spoken at home), differences in educational performance continue to exist across migrants from different regions of origin and across migrants living in different destination countries (Schnepf 2006; Marks 2005; Levels and Dronkers, 2008). In order to explain the remaining cross-group and cross-national variation, Levels, Dronkers, and Kraaykamp (2008) have examined the relevance of a range of contextual features of both countries of origin and destination. Their results indicate that several macro-characteristics of both destination and origin countries affect the educational performance of migrant children. For example, migrant children from politically stable origin countries perform better at school than their counterparts from less stable countries. Also, origin countries' level of economic development negatively affects educational performance. At the destination level, migrant children living in traditional immigration countries (Australia and New Zealand) have higher levels of educational performance. Levels et al. (2008) conclude that an exclusive focus on individual qualities cannot sufficiently explain the educational performance of migrant children. Contextual features of both origin and destination countries do affect the educational performance of migrant children, and must be part of any explanation of migrant children's school success.

The study of contextual effects on migrant pupils' scholastic performance is relatively recent. This study examines the influence of three important aspects of educational systems on the educational performance of migrant children. National education systems differ for instance in the number of distinct educational programs at secondary 
education, the age at which children are selected into different educational programs, and the existence of nationally standardized examinations at the end of primary and secondary education (Shavit and Blossfeld, 1993; Shavit and Müller, 1998). Although these different educational structures have been suggested to explain differences in the educational success of migrants across countries, there is little systematic evidence for this claim (Buchmann and Parrado, 2006; Heath and Birnbaum, 2007). Moreover, no study so far has taken into account educational system features of migrant children's countries of origin. Since first generation migrant children might have attended school in their origin countries (Rumbaut, 2004), their educational performance is partly determined by the structure and organization of education in those countries. Therefore, in order to establish the effects of educational systems on the scholastic performance of migrant children, characteristics of educational systems of origin countries must be studied. Levels et al. (2008) analyzed only general macro-characteristics of the origin and destination countries and found significant effects of economic development and political stability of the origin countries. However, these results might be explained by features of the educational systems of the countries of origin and destination, because the level of economic development and political stability will be related to some characteristics of educational systems. Therefore we try to answer the following research question: To what extent is the educational performance of 15-year-old migrant children determined by the degree of differentiation and standardization and the level of resources of educational systems of both their countries of origin and destination, also after controlling for the economic and political macro-characteristics of the countries of origin?

\section{Educational systems of origin and destination}

Important aspects of national education systems are the number of distinct educational tracks at secondary education, the age at which children are selected into different educational programs, the existence of nationally standardized examinations at the end of primary and secondary education and the availability of resources for teaching and learning (Shavit and Müller, 1998; Buchmann \& Hannun, 2001). But in many other, often less tangible ways, national educational systems differ also: pedagogical practices, the nature of the curriculum, the status of teachers, the balance of power between various actors with the system (parents, teachers, school-boards, local authorities, national government). In this article we concentrate on three aspects of educational systems: the degree of differentiation, the degree of standardization, and the availability of resources. We have theoretical as well as practical arguments for this limitation. These three characteristics (differentiation, standardization, resources) are the most commonly mentioned in the literature (Buchmann and Hannum, 2001; Dunne, 2010; Shavit and Müller, 1998; Wössmann, 2003) as the most important educational system features, which influence the strength of the relation between socio-economic parental backgrounds and educational outcomes. We assume that the immigration background of pupils is another aspect of parental background and thus that the relation between educational outcomes and immigration background is also strongest influenced by these three aspects of educational systems. Our more practical argument to focus only on differentiation, standardization, and resources is that the small number of destination countries (16) in the best available cross-national data-set (PISA data) makes it impossible to include all possible features of educational 
systems in the analysis. An additional argument for our focus is that many possible characteristics of educational systems lack reliable cross-national indicators for the origin and destination countries at hand.

We will assume that origin countries' educational systems affect migrant children's educational outcome in their destination country only if they have received part of their education in their origin country. So, we do not expect direct effects of origin countries' education systems for the scholastic performance of second-generation migrant children, who are born in a country to which their parents migrated. Moreover, the more time first generation migrant children have received education in their origin country, the more relevant the education system of the origin country will be. Rumbaut (2004) has shown that educational performance of first generation migrant children differs extensively between children who have migrated at an early age and children who have migrated later in life. Following Rumbaut's (ibid.) terminology, we distinguish between first generation children who have migrated before the age of 5 , children who have migrated between the age of 5 and 12, and pupils who migrated after the age of 12 .

\section{Differentiation}

Differentiation of the education system refers to the extent to which pupils of the same age are divided into separate types of education. Whereas highly stratified systems select and allocate pupils into different types of secondary education at a relatively young age, systems that are less stratified postpone that decision until a later age. In moderate stratified systems, pupils are streamed early inside schools according to ability or different school-types are offered within the same school. Although the American high school system offers the same type of education to all high school pupils, it is characterized by a high degree of internal ability grouping. High achievers are generally assigned to 'honors' sections of a certain course; low achievers attend 'remedial' sections (Slavin, 1990; Gamoran, Nystrand, Berends and LePorc, 1995). In comprehensive educational systems (like in Scandinavia) all pupils attend the same school-type and there exists hardly any institutional tracking or streaming within these schools $\mathrm{s}^{\mathrm{a}}$.

The early differentiation influences the educational choices of children of lower class parents (natives and migrants) negatively. The rationale behind this is that educational choices made at a relatively early age are more heavily influenced by parental background than by children's actual achievements (Mare, 1981; Shavit and Blossfeld, 1993). Pfeffer (2008) has recently underscored the importance of parents' strategic knowledge of the education system as a crucial resource that translates into different educational choices. Parents' strategic knowledge is especially important in highly stratified systems. Migrants are on average less knowledgeable of the different educational options in their destination countries and will therefore be less able to navigate their children successfully through the more differentiated educational systems. More general, as a result of a lower level of resources of migrants (educational, occupational, knowledge of the educational system, a lower command of the host country's language) their children are more likely to be selected and allocated into lower educational streams and school-types (van de Werfhorst and van Tubergen, 2007).

The early institutional differentiation, either by different school-types or by streams within undifferentiated secondary schools, is related to curricular differentiation between the students. The curriculum is varying by school-type or the level of the stream. 
One of the most important differences in curriculum is that between vocational and general education. The curriculum offered in vocational education tends to be more restricted to practical skills instead of more abstract knowledge. This might lead to differences in educational performance between comparable students from general and vocational education. Also the more a school-type or a stream prepares students for college or university entrance, the more demanding the curriculum, the higher the criteria for academic success but also the opportunities for the students to learn more and perform better. This curriculum differentiation at an early age gives comparable 15-year old migrant students in school-types and streams unequal opportunities to learn certain knowledge and skills (Baker \& LeTendre, 2005).

One of the aims of this early institutional differentiation is the creation of homogeneous learning environments. The central argument behind different school-types, tracking or ability grouping is that homogeneous learning environments permit a focused curriculum and paced instruction, which increases the average performance of all students (Hanushek and Wössmann, 2005). This homogenization influences the ability composition of the school-type and the stream. The more demanding school-types or streams will have on average more students with higher scholastic skills, while the less demanding schooltypes or streams will have on average more students with lower demanding skills. This differentiation of ability composition of the student body between school-types and streams creates different opportunities for teaching and learning, both by the available time-on-task, the various criteria of teachers and students and the peer-group pressure for academic and non-academic success (Coleman et al, 1966; Scheerens and Bosker, 1997; Dronkers, 2010).

Given the lower resources of many migrant parents, their larger difficulties to gain early access for their children to those streams or school-types, which offer a more demanding curriculum and better teaching and learning environment, we hypothesize that the educational achievement of 15-year-old migrant children will be lowest in destination countries with highly and a moderately stratified educational systems in comparison with the educational achievement of 15-year-old migrant children in destination countries with a comprehensive educational system (hypothesis 1).

\section{Standardization}

Standardization refers to the degree to which external standards exist in an educational system to maintain the quality level of the education. External standards give a set of standard rules and guidelines to schools, with which they have to comply (Wössmann, 2003). The best cross-national indicator for an external standard is a nationally standardized exam at the end of secondary education ${ }^{\mathrm{b}}$. Since all students in a country attending the same school-type will face the same test at the end of secondary education, schools have an incentive to keep the quality of their education sufficiently high. After all, failing to warrant high quality education in a standardized system would most likely lead to lower average scores on the exams and might consequently damage an educational system's reputation (Bishop, 1997). We therefore hypothesize that the existence of national exam in destination countries has a positive influence on the educational achievement of migrant children living in this country (hypothesis $2 A$ ).

Moreover, the degree of standardization of the educational system of migrant children's countries of origin is expected to affect the educational achievement of migrant children who attended part of their education in their origin country. In our case out 
best indicator of standardization in the countries of origin is the length of compulsory education, and not a national standardized exam, because for that later indicator is for many origin countries not valid. Whereas second generation migrants and migrant children who arrive before the age of 5 did not attend education in their origin country, migrant children with an age higher than 5 have been shaped by their origin countries' educational systems. Therefore we hypothesize that the length of compulsory education of migrant children's countries of origin positively affects the educational achievement of migrants originating from these countries, and this is especially the case for migrant children who were 5 year or older at their arrival, and not for the second generation and migrant children who were less than 5 year old at their arrival (hypothesis 2B).

\section{Resources to teach and learn}

Educational achievement can be expected to be determined by the amount of time spent on teaching ('teaching time') and learning ('learning time'). Overall, the more teaching hours students receive and the more time they spend processing this information, the better their educational performance is likely to be (Ammermüller, 2005; Scheerens \& Bosker, 1997). The learning and teaching time an educational system can provide for depends on the allocation of its human and material resources. National governments invest money in educating teachers, reducing teacher shortages, and equipping schools with modern information technologies in order to keep the quality of education high. However, research into the influence of school quality on educational achievement has suggested that school resources only have a very limited influence on pupils' performances. Coleman et al. (1966) revealed that, relative to students' individual background characteristics, measured differences in school resources (e.g. per pupil spending) matter little in determining educational outcomes of pupils in the US. Later studies focusing in the US or other Western countries have revealed a similar weak influence of material school resources (Dronkers, 2010). Studies focusing on educational achievement in less developed countries have suggested that this might be related to the relatively low variance in educational resources within and across developed industrial nations. In developing nations, material and human resources such as the availability of textbooks and teacher training have shown to strongly determine achievement (see e.g. Heyneman and Loxley, 1983, and an elaborate review by Buchmann and Hannum, 2001).

Despite the limited support for a positive influence of educational systems' resources on educational achievement across developed countries, the picture might look differently for migrant children. Next to having a socioeconomic disadvantage to natives, migrant children's educational performance is also hindered by specific migrant characteristics, like the mastery of the language of the destination country. Migrant parents' limited knowledge of the education system and their restricted language skills hinder their possibilities to help their children with their homework or prepare them for tests. Therefore the educational achievement of migrant children have to depend more on the resources provided by the educational systems and schools of their destination countries than native pupils have to (Scheerens \& Bosker, 1997). We test the following hypothesis: the quality of resources of a destination country's educational system positively affects the educational performance of migrant children living in this country (hypothesis $3 A$ ).

The same reasoning applies to the resources educational systems in origin countries possess. The educational achievement of migrant children who attended part of their 
education in their origin country, is likely to be affected by the quality of the resources of their origin country's educational system. It is expected that the quality of resources of an origin country's educational system positively affects the educational performance of migrant children originating from this country, and this is especially the case for migrant children who were 5 year or older at their arrival, and less for the second generation and migrant children who were less than 5 year old at their arrival (hypothesis 3B).

We will control our results for two macro-characteristics of the countries of origin shown to affects educational performance of migrant children: i.e. economic prosperity and political stability (Levels et al. 2008). Both indicators refer to two important push factors for immigration: lack of economic prosperity and political unrest. In this way we want to ascertain that the effects of the educational systems are not spurious and explainable by economic prosperity and political stability of the origin countries.

\section{Data}

The 2006 data from the Program for International Student Assessment [PISA], initiated by the Organization for Economic Co-operation and Development [OECD], were used to test the hypotheses of this study. Since 2000, the OECD has conducted large scale tests among 15-year-olds living in its member states and partner states every three years. Pupils' mathematical, reading, and scientific literacy were assessed. In doing so, the OECD aimed to find out to what degree pupils near the end of compulsory education have acquired knowledge and skills essential for full participation in society. The main focus of the 2006 study was on scientific literacy (OECD, 2007). Therefore we use this scientific literacy score as dependent variable ${ }^{c}$. PISA also provides information on individual and school characteristics by respectively administering a student and a principal questionnaire. Each school's principal is asked to provide information on numerous school characteristics, such as the teacher-student ratio, the number of vacant science positions, and the school's location. The student questionnaire asks students to provide detailed information on parental education and occupations, resources available at home, the language spoken at home and the birth countries of both the parents and the student. Since specific information on the birth country of both the parents and the student is essential to our analysis, we could only use countries that measured with enough specificity birth countries. Therefore, although not less than 57 countries participated in the 2006 PISA wave, only data from the following 16 developed countries are suited to test our hypotheses: Australia, Austria, Belgium, Denmark, Finland, Germany, Greece, Latvia, Liechtenstein, Luxembourg, the Netherlands, New Zealand, Norway, Portugal, Switzerland and Scotland ${ }^{\mathrm{d}}$. We excluded all pupils from those countries of origin were unknown or which had in total less than 30 cases $^{\mathrm{e}}$. Therefore we analyze 9.279 migrant pupils from 35 different countries of origin in 16 countries of destination ${ }^{\mathrm{f}}$.

This selection of pupils who gave valid information on the countries of birth of themselves and their parents reduced sharply the number of pupils with missing values on one of the independent variables ${ }^{\mathrm{g}}$. In order not to lose those few pupils with missing values, we imputed each missing value with the average score on that independent variable of the migrant pupils with the same combination of origin and destination. Only for the variables migrant generation (age at arrival) and language spoken at home the numbers of pupils with missing values were substantial (see Table 1). In these latter 
Table 1 Descriptive statistics of all variables in analysis $(N=9.279)$

\begin{tabular}{|c|c|c|c|c|}
\hline & Min. & Max. & Mean & S.d. \\
\hline \multicolumn{5}{|l|}{ Dependent variable } \\
\hline Scientific literacy & 130.30 & 841.04 & 468.63 & 103.20 \\
\hline \multicolumn{5}{|l|}{ Destination variables } \\
\hline Average science performance natives & 479.77 & 565.41 & 523.08 & 12.68 \\
\hline \multicolumn{5}{|l|}{ Resources } \\
\hline Quality educational resources & -0.55 & 0.88 & 0.29 & 0.29 \\
\hline Degree of teacher shortage & -0.83 & 1.05 & 0.24 & 0.43 \\
\hline Student-teacher ratio in primary education & 10 & 18 & 13.64 & 2.59 \\
\hline \multicolumn{5}{|l|}{ Standardisation } \\
\hline Nationally standardized exams science & 0 & 1 & 0.57 & 0.50 \\
\hline \multicolumn{5}{|l|}{ Differentiation } \\
\hline Highly stratified system & 0 & 1 & 0.31 & 0.46 \\
\hline Moderately differentiated system & 0 & 1 & 0.25 & 0.47 \\
\hline Comprehensive system (ref.) & 0 & 1 & 0.44 & 0.48 \\
\hline \multicolumn{5}{|l|}{ Origin variables } \\
\hline \multicolumn{5}{|l|}{ Resources } \\
\hline EDI-score & 0.75 & 0.99 & 0.94 & 0.05 \\
\hline Student-teacher ratio in primary education & 10 & 40 & 19.70 & 7.41 \\
\hline \multicolumn{5}{|l|}{ Standardisation } \\
\hline Compulsory years of education & 5 & 13 & 9.76 & 1.55 \\
\hline \multicolumn{5}{|l|}{ Economic and Political Features } \\
\hline Human Development Index & 0.41 & 0.96 & .85 & 0.10 \\
\hline Political stability & -2.31 & 1.92 & 0.04 & 0.74 \\
\hline \multicolumn{5}{|l|}{ Individual-level variables } \\
\hline Vocational type of education & 0 & 1 & 0.16 & 0.37 \\
\hline Grade & -3 & 3 & 0.04 & 0.64 \\
\hline Girls & 0 & 1 & 0.50 & 0.50 \\
\hline Parental education & 0 & 6 & 3.92 & 1.85 \\
\hline Parental occupation & 16 & 90 & 44.55 & 16.87 \\
\hline Home possessions & -5.12 & 4.02 & -0.11 & 0.87 \\
\hline \multicolumn{5}{|l|}{ Migrant characteristics } \\
\hline Second generation (ref.) & 0 & 1 & 0.51 & 0.50 \\
\hline 1.75 generation & 0 & 1 & 0.24 & 0.43 \\
\hline 1.5 generation & 0 & 1 & 0.16 & 0.36 \\
\hline 1.25 generation & 0 & 1 & 0.06 & 0.23 \\
\hline Migrant generation unknown & 0 & 1 & 0.04 & 0.19 \\
\hline One native parent & 0 & 1 & 0.06 & 0.23 \\
\hline Language of test country spoken at home & 0 & 1 & 0.50 & 0.50 \\
\hline Language spoken at home unknown & 0 & 1 & 0.11 & 0.31 \\
\hline
\end{tabular}

two cases we made additional dummies to indicate whether a pupil had a missing value on these variables and included these dummies to the equations.

PISA data are unique as cross-national data, but they are only cross-sectional and not longitudinal data. This sets limits to the conclusions, which we can draw from 
these data. With cross-sectional data, we can only establish associations or relationships between variables (for instance between a characteristic of the secondary education system and educational performance of the pupils in these systems), but cannot rule out whether this association is not caused by an other variable, earlier in the career of the pupil (for instance the quality of primary education or the health care in these countries). Although we use a terminology, which suggests causation, the readers should be aware that we couldn't prove causality with the cross-sectional international data at hand.

\section{Variables}

\section{Dependent variable}

The dependent variable of this study is scientific literacy. In order to be able to cover as many facets from the scientific field as possible (in general, the scientific field should be regarded as a combination of the disciplines Biology, Physics, Chemistry and Geography, covering topics such as health, natural resources and environment), a test with a total assessment time of 390 minutes was developed. However, since it would not be sensible to administer a test of more than 6 hours to an individual pupil, 13 largely comparable item clusters, with a duration of 2 hours each, were derived from the core test. These booklets were allocated to individual students according to a random selection process. Since two booklets can never have exactly the same average difficulty, Item Response Modeling was used by PISA to establish comparable science results across students. We averaged the five plausible scores on scientific literacy. We were forced to use this average score, because the current statistical packages do not allow for the combination of crossclassified multilevel regression and different plausible values (see section 'analyses and results', paragraph 'methods').

\section{Educational system features of countries of destination}

Information on destination countries' educational systems has been derived from PISA 2006, by aggregating these school characteristics to the destination country level, also using schools with only native pupils. The principal provided these school characteristics.

Quality of educational resources is an index composed by PISA (IRT scaling) that indicates to what extent instruction at school is hindered by the following factors: shortage or inadequacy of science laboratory equipment, shortage or inadequacy of instructional materials (e.g. textbooks), shortage or inadequacy of computers for instruction, lack or inadequacy of internet connectivity, shortage or inadequacy of computer software for instruction, shortage or inadequacy of library materials, shortage or inadequacy of audio-visual resources. Positive values refer to higher quality resources in a country of destination.

The degree of teacher shortage is an index provided by PISA (IRT scaling) that indicates the extent to which extent instruction is hindered by the following factors: a lack of qualified science teachers, a lack of qualified mathematics teachers, a lack of qualified language teachers, and a lack of qualified teachers of other subjects. Positive values refer to countries with higher teacher shortages.

Nationally standardized exam is a dummy variable that indicates whether a destination country has nationally standardized examinations in science at the end of secondary education. This is the case in Australia, Germany, Denmark, Finland, Liechtenstein, Luxembourg, Latvia, the Netherlands, Norway, New Zealand, and Scotland (1) and not in Austria, Belgium, 
Switzerland, Greece, and Portugal (0, reference category). This information has been derived from additional information provided by PISA (OECD2007, Table 5.2).

To measure the level of differentiation of the educational system, we classified countries according to their stratification level. This was based on the first age at which pupils have to choose between different educational types, the number of types pupils can choose between, and the presence of more types of internal ability grouping or tracking. Although PISA provides this information for all countries in the sample, we have consulted additional descriptions of national experts (Schneider, 2008; Shavit and Müller, 1998; UNESCO 2007). Overall, the different sources have revealed a similar pattern. In the highly stratified countries, children can choose between at least 3 different educational types at age 10 (Germany, Austria), 11 (Liechtenstein), or 12 (Switzerland, the Netherlands). In comprehensive systems, children are not selected into different educational types before age 15 and they are not tracked within their common schools. We define Austria, Switzerland, Germany, Liechtenstein, and the Netherlands as highly stratified systems; Belgium, Greece, Portugal, and Luxembourg as moderately stratified systems; and Finland, Norway, Denmark, New Zealand, Australia, Scotland, and Latvia as systems that are hardly stratified. We use dummy variables indicating whether countries have a highly stratified, moderately differentiated or comprehensive education system. The latter is the reference category.

\section{Educational system features of countries of origin}

Information on educational systems of origin countries' educational systems has been derived from World Data on Education 2006/2007.

The Education for All Development Index (EDI) is a composite expressing to what degree a origin country succeeds in providing education for all. It consists of a country's total primary net enrolment ratio (the percentage of primary-school-age children who are enrolled in either primary or secondary school), the survival rate up to grade 5 , adult literacy, and gender parity in primary and secondary education. It ranges from 0,75 (Morocco) to 0,99 (e.g. Germany, France, and Sweden). The EDI-scores reflect the situation in 2004.

The student-teacher ratio in primary education was taken into account at both the origin and destination level. At the origin level, it ranges from 10 to 40 students per teacher, with an overall average of slightly less than 20 students per teacher for all origin countries. At the destination level, it ranges from 10 to 18. Data have been gathered in 2006.

Years of compulsory education refers to the duration of compulsory schooling in countries of origin. On average for all origin countries in our data, pupils are obliged to attend school for slightly less than 10 years. The mandatory length of schooling varies considerably between origin countries, from 5 to 13 years. Again, data reflect the situation in 2006.

\section{Macro-economic characteristics of countries of origin}

A country's level of economic development was approached by its Human Development Index (HDI) (2007). It provides a broad picture of a county's human development level. Ranging from 0 to 1, the Human Development Index (2007/2008) combines information on countries' life expectancies, adult literacy rates, gross enrolment ratios in primary, secondary, and tertiary education, and GDPs in order to measure countries' levels of human development. The countries political stability is measured with the World Bank Government 
Indicator for political stability (Kaufmann, Kraay and Mastruzzi 2005). The measurement represents the perceived likelihood of revolutionary regime-change by violent or otherwise unconstitutional means. A higher score refers to a more stable political situation.

\section{Individual level variables}

In line with Rumbaut (2004), we have constructed migrant generation variables that combine information on the birth countries of both the parents and the pupil and his/ her age of migration. Second generation migrant children are those pupils of whom at least one parent was born abroad, but who have been born in the current destination country themselves. First generation migrant pupils have been born abroad themselves as well. If the age of migration of first generation migrant pupils was before age 5, those pupils have been labeled 1.75 generation migrant pupils. The 1.5 generation refers to first generation pupils who have migrated between the age of 5 and 12, and the 1.25 generation refers to those pupils who migrated after the age of 12. First generation migrant pupils without an age of arrival got the average age of their combination of origin and destination country. We also created an migrant generation missing dummy variable. Second generation migrants are used as the reference category.

One native parent A dummy variable was used to identify pupils who had one migrant and one native-born parent (1); pupils with two non-native parents represent the reference group (0).

Official language of destination country spoken at home We included a dummy variable to differentiate migrant children who speak one of their destination country's official languages at home (1) from children who speak a foreign language (0). Migrant pupils without a valide answer on this question got the average answer of their combination of origin and destination country. We also created a language missing dummy variable.

Parental occupational status is measured according to the ISEI scale (Ganzeboom, de Graaf, Treiman, and de Leeuw, 1992), which ranges from 16 to 90. We use the ISEI score of the parent with the highest occupational status.

Parental educational level is measured according to the ISCED scale (UNESCO, 2006) and ranges from 0 to 6 . We use the ISCED level of the highest educated parent.

Home possessions is a summary index of the amount of material and cultural goods that are available at home. It is a combined measure of the availability of a study desk, a private room, a quiet place to study, a computer, educational software, access to the internet, classic literature or poetry books, works of art, books to help with school work, a dictionary, a dishwasher, and more than 100 books. A higher score indicates a higher level of home possessions.

Vocational education A dummy variable indicates whether a pupil is currently enrolled in a vocational (1) or general (0) type of education. This division has been adopted from the ISCED classification.

Grade Since not all pupils attend the same grade, we have included a variable to account for this. As a result of between-country variance in the counting of grades, we have standardized grade around the modal grade in a country. 
Female We control for gender-effects by using a dummy variable indicating whether a pupil is female (1) or male (0).

\section{Analyses and results Methods}

To analyze non-hierarchically structured data, cross-classified multilevel regression analyses are appropriate (Snijders and Bosker, 1999). We used Iterative Generalized Least Squares (IGLS) estimation techniques from the statistical analysis program MLwiN to estimate models (Browne, 2003). Although originally designed to fit hierarchical models, IGLS can also be adapted to non-hierarchical data structures. IGLS is based on an iterative procedure which provides point estimates for all parameters, including their standard deviations. We make use of a double comparative design ( $c f$. Van Tubergen, 2006; Levels et al., 2008), that models variance between origin countries and variance between destination countries simultaneously. This is necessary in order to disentangle the various macro-level effects. An additional advantage of this double comparative multilevel approach is that the variation of (unmeasured) factors, unique to each destination or origin country, are captured by the random intercept at the origin and destination levels and thus does not cause much bias in the parameters of the measured variables.

In this cross-classified multilevel analysis the two highest levels (origin and destination) are non-hierarchical, while the lower hierarchical level is the pupil-level. We include the measurement error of the five plausible values on science test as one of the error terms of the regression ${ }^{\mathrm{h}}$. This procedure is sometimes called the Known Variance Approach (also used in meta-analyses, which apply multi-level techniques). This known measurement error approach results in a more reliable estimation of the true score of the dependent variable and thus more correct parameters of the independent variables (see Hox, 2002, chapter 8; Raudenbush \& Bryk, 2002). The results of multilevel analyses with this measurement model are comparable to results using all the plausible values and averaging the coefficients. As said earlier, the current statistical packages do not allow for the combination of cross-classified multilevel regression and different plausible values. ${ }^{\mathrm{i}}$.

As a consequence of the double comparative design, native pupils cannot be included in our analysis, since for native pupils the origin country equals the destination country. However, in order to account for the fact that in some destination countries the average performance of all pupils is higher than in others (as an indicator of the general quality of schooling), the average science performance of natives per destination country is added as a variable to the analysis. This approach has been suggested by van Tubergen (2006) and was adopted by Levels et al. (2008). We apply this approach because in this analysis we do not want to explain differences in average performances of pupils (both natives and migrant) in different countries, but we focus on the differences in the performance of migrant pupils in these countries ${ }^{j}$.

\section{Descriptive results}

Table 2 presents the average scientific performance of migrant pupils per destination and origin country. On average, the 9.279 migrant pupils living in our 16 destination countries have a scientific literacy score of 468 , which is 32 points below the OECD mean. However, the overall migrant mean of 468 conceals the considerable variation by 
Table 2 Average scientific literacy of migrant pupils per country of destination and country of origin $(\mathrm{N}=9.279)$

\begin{tabular}{|c|c|c|c|c|c|c|c|c|c|c|c|c|c|c|c|c|c|}
\hline \multirow[b]{2}{*}{ Origin countries } & \multicolumn{17}{|c|}{ Destination countries } \\
\hline & $\mathrm{AU}$ & AT & $\mathrm{BE}$ & $\mathrm{CH}$ & $\mathrm{DE}$ & DK & EL & $\mathrm{Fl}$ & $\mathrm{LI}$ & LU & LV & $\mathrm{NL}$ & $\mathrm{NO}$ & NZ & PT & SC & Mean \\
\hline Albania & 0 & 412 & 0 & 359 & 0 & 0 & 434 & 0 & 358 & 0 & 0 & 0 & 0 & 0 & 0 & 0 & 404 \\
\hline Australia & 0 & 0 & 0 & 0 & 0 & 0 & 0 & 0 & 0 & 0 & 0 & 0 & 0 & 548 & 0 & 0 & 548 \\
\hline Austria & 0 & 0 & 0 & 495 & 0 & 0 & 0 & 0 & 554 & 0 & 0 & 0 & 0 & 0 & 0 & 0 & 519 \\
\hline Belarus & 0 & 0 & 0 & 0 & 0 & 0 & 0 & 0 & 0 & 0 & 504 & 0 & 0 & 0 & 0 & 0 & 504 \\
\hline Belgium & 0 & 0 & 0 & 0 & 0 & 0 & 0 & 0 & 0 & 528 & 0 & 0 & 0 & 0 & 0 & 0 & 528 \\
\hline Bosnia Herzegovina & 0 & 445 & 0 & 0 & 451 & 421 & 0 & 0 & 0 & 0 & 0 & 0 & 0 & 0 & 0 & 0 & 440 \\
\hline Brazil & 0 & 0 & 0 & 0 & 0 & 0 & 0 & 0 & 0 & 0 & 0 & 0 & 0 & 0 & 464 & 0 & 464 \\
\hline Cap Verde & 0 & 0 & 0 & 0 & 0 & 0 & 0 & 0 & 0 & 380 & 0 & 0 & 0 & 0 & 0 & 0 & 380 \\
\hline China & 562 & 518 & 0 & 0 & 0 & 0 & 0 & 0 & 0 & 0 & 0 & 0 & 0 & 547 & 458 & 483 & 552 \\
\hline Congo & 0 & 0 & 427 & 0 & 0 & 0 & 0 & 0 & 0 & 0 & 0 & 0 & 0 & 0 & 0 & 0 & 427 \\
\hline Croatia & 0 & 458 & 0 & 0 & 433 & 0 & 0 & 0 & 0 & 0 & 0 & 0 & 0 & 0 & 0 & 0 & 451 \\
\hline France & 0 & 0 & 448 & 507 & 0 & 0 & 0 & 0 & 446 & 505 & 0 & 0 & 0 & 0 & 0 & 0 & 488 \\
\hline Germany & 0 & 521 & 508 & 549 & 0 & 0 & 0 & 0 & 550 & 532 & 0 & 504 & 0 & 0 & 0 & 0 & 526 \\
\hline India & 551 & 0 & 0 & 0 & 0 & 0 & 0 & 0 & 0 & 0 & 0 & 0 & 0 & 0 & 0 & 541 & 551 \\
\hline Italy & 0 & 0 & 0 & 443 & 415 & 0 & 0 & 0 & 445 & 430 & 0 & 0 & 0 & 0 & 0 & 0 & 438 \\
\hline Rep. of Korea & 514 & 0 & 0 & 0 & 0 & 0 & 0 & 0 & 0 & 0 & 0 & 0 & 0 & 528 & 0 & 0 & 521 \\
\hline Morocco & 0 & 0 & 438 & 0 & 0 & 0 & 0 & 0 & 0 & 0 & 0 & 0 & 0 & 0 & 0 & 0 & 438 \\
\hline Netherlands & 0 & 0 & 522 & 0 & 0 & 0 & 0 & 0 & 0 & 0 & 0 & 0 & 0 & 0 & 0 & 0 & 522 \\
\hline New Zealand & 508 & 0 & 0 & 0 & 0 & 0 & 0 & 0 & 0 & 0 & 0 & 0 & 0 & 0 & 0 & 0 & 508 \\
\hline Pakistan & 0 & 0 & 0 & 0 & 0 & 383 & 0 & 0 & 0 & 0 & 0 & 0 & 0 & 0 & 0 & 454 & 412 \\
\hline Philippines & 512 & 0 & 0 & 0 & 0 & 0 & 0 & 0 & 0 & 0 & 0 & 0 & 0 & 0 & 0 & 0 & 512 \\
\hline Portugal & 0 & 0 & 0 & 454 & 0 & 0 & 0 & 0 & 445 & 420 & 0 & 0 & 0 & 0 & 0 & 0 & 428 \\
\hline Russia & 0 & 0 & 0 & 0 & 466 & 0 & 0 & 550 & 0 & 0 & 496 & 0 & 0 & 0 & 0 & 0 & 493 \\
\hline
\end{tabular}


Table 2 Average scientific literacy of migrant pupils per country of destination and country of origin ( $\mathbf{N}=\mathbf{9 . 2 7 9 )}($ Continued)

\begin{tabular}{|c|c|c|c|c|c|c|c|c|c|c|c|c|c|c|c|c|c|}
\hline Samoa & 0 & 0 & 0 & 0 & 0 & 0 & 0 & 0 & 0 & 0 & 0 & 0 & 0 & 425 & 0 & 0 & 425 \\
\hline Serbia Montenegro & 0 & 426 & 0 & 427 & 414 & 0 & 0 & 0 & 417 & 0 & 0 & 0 & 0 & 0 & 0 & 0 & 420 \\
\hline South Africa & 541 & 0 & 0 & 0 & 0 & 0 & 0 & 0 & 0 & 0 & 0 & 0 & 0 & 0 & 0 & 0 & 541 \\
\hline Spain & 0 & 0 & 0 & 466 & 0 & 0 & 0 & 0 & 516 & 0 & 0 & 0 & 0 & 0 & 0 & 0 & 467 \\
\hline Sweden & 0 & 0 & 0 & 0 & 0 & 0 & 0 & 522 & 0 & 0 & 0 & 0 & 465 & 0 & 0 & 0 & 477 \\
\hline Switzerland & 0 & 0 & 0 & 0 & 0 & 0 & 0 & 0 & 521 & 0 & 0 & 0 & 0 & 0 & 0 & 0 & 521 \\
\hline Turkey & 0 & 380 & 414 & 425 & 411 & 374 & 0 & 0 & 389 & 0 & 0 & 466 & 0 & 0 & 0 & 0 & 429 \\
\hline Ukraine & 0 & 0 & 0 & 0 & 0 & 0 & 0 & 0 & 0 & 0 & 472 & 0 & 0 & 0 & 0 & 0 & 472 \\
\hline United Kingdom & 542 & 0 & 0 & 0 & 0 & 0 & 0 & 0 & 0 & 0 & 0 & 0 & 0 & 569 & 0 & 0 & 550 \\
\hline United States & 571 & 0 & 0 & 0 & 0 & 0 & 0 & 0 & 0 & 0 & 0 & 0 & 0 & 0 & 0 & 0 & 571 \\
\hline Vietnam & 518 & 0 & 0 & 0 & 0 & 0 & 0 & 0 & 0 & 0 & 0 & 0 & 0 & 0 & 0 & 0 & 518 \\
\hline Mean migrants & 536 & 437 & 453 & 444 & 438 & 388 & 434 & 522 & 498 & 455 & 492 & 472 & 444 & 525 & 464 & 474 & 468 \\
\hline Mean natives & 524 & 525 & 527 & 527 & 531 & 501 & 480 & 565 & 540 & 512 & 495 & 540 & 492 & 537 & 482 & 516 & 518 \\
\hline Difference (I-N) & 12 & -88 & -74 & -83 & -93 & -113 & -46 & -43 & -42 & -67 & -3 & -68 & -48 & -12 & -18 & -42 & -50 \\
\hline
\end{tabular}

Notes: Destination countries: AU = Australia; AT = Austria; $\mathrm{BE}=$ Belgium; $\mathrm{CH}=$ Switzerland; $\mathrm{DE}=$ Germany; $\mathrm{DK}=$ Denmark; $\mathrm{EL}=\mathrm{Greece} ; \mathrm{Fl}=$ Finland; $\mathrm{LI}=\mathrm{Liechtenstein;} \mathrm{LU}=\mathrm{Luxembourg} ; \mathrm{LV}=\mathrm{Latvia}$ : $\mathrm{NL}=\mathrm{Netherlands;}$ $\mathrm{NO}=$ Norway; $\mathrm{NZ}=$ New Zealand; $\mathrm{PT}=$ Portugal; $\mathrm{SC}=\mathrm{Scotland}$. Source: PISA 2006 
origin and destination country. The difference between the lowest and highest performing origin group is almost 200; migrant pupils from Cap Verde have an average science score of 380, migrant pupils from the United States have an average score of 571. Other high performers are the Chinese and Australian migrants (552 and 548 respectively). Those variable scores of migrants originating from different countries might indicate the existence of origin effects. Next to those apparent origin effects, destination effects seem to exist as well. Whereas migrant pupils living in Australia have an average science score of 536, migrant pupils in Denmark have a score of no higher than 388. So, science performance of migrants also differs across different countries of destination.

\section{Variance components}

The cross-classified multilevel model, which does not include any explanatory variables, gives the distribution of unexplained variance across three levels (model 0, Table 3). By far the most variance occurs at the individual level (72\%). Since our data set contains 16 relatively homogeneous (developed) destination countries, the small variance at the destination level $(8 \%)$ is not surprising. A larger amount of variance can be attributed to variance across origin groups: $20 \%$ of all variance in the educational achievement of migrant pupils can be attributed to the countries migrant children migrated from. So, although variance at the individual level accounts for the largest share of differences in educational achievement, a quarter of those differences exists at contextual levels ${ }^{\mathrm{k}}$.

\section{Individual effects}

In model 1 of Table 3, a range of individual-level characteristics and the average science score of the native pupils per destination county is added to the initial empty model 0 . Taking into account individual-level variables is not only important because the majority of variance in scientific literacy is caused by individual-level predictors, but also because they allow the detection of composition effects (Hox, 2002). Migrants in one destination country might outperform migrants in another, not because of contextual effects, but because destination countries host migrant pupils with different individual background characteristics. The same reasoning applies to migrants originating from different origins. In order to rule out individual background differences across different origin groups, individual-level variables have to be taken into account.

Most results are in line with earlier research. Parental education and occupation, and home possessions have a large positive influence on scientific literacy. This strong influence of parental class position on educational achievement or attainment has been widely documented for natives in many Western countries (see e.g. Shavit and Blossfeld, 1993, and more recently, Breen, Luijkx, Müller, and Pollak, 2009). Moreover, migrant children who speak their host country's language at home perform better at school than their counterparts who do not. Interesting is the large negative effect of attending vocational types of education. Comparable migrant pupils who attend vocational education perform 55 points less on the science scale than migrant pupils who attend general types of education. This finding might reflect the differences in the offered curriculum: whereas vocational education types pay more attention to practical skills needed at the labor market, general types of education more heavily focus on more abstract knowledge, also related to later entrance of college or university. The grade of the 15-year old pupil has a strong effect on educational outcomes, reflecting both 
Table 3 Cross-classified regression of educational system characteristics of countries of origin and destination, controlled for individual characteristics, on the scientific literacy of migrant pupils; $\mathrm{Nd}=16, \mathrm{No}=35, \mathrm{Ni}=9.279$

\begin{tabular}{|c|c|c|c|c|c|c|}
\hline & Model 0 & Model 1 & Model 2 & Model 3 & Model 4 & Model 5 \\
\hline Intercept & $474.45^{* *}(9.04)$ & $16.03(172.09)$ & $92.59(156.78)$ & $134.16(158.19)$ & $124.17(158.80)$ & $44.35(169.03)$ \\
\hline \multicolumn{7}{|l|}{ Destination effects of education } \\
\hline Average science performance natives & & $0.78^{* *}(0.33)$ & $0.28(0.34)$ & $0.18(0.34)$ & $0.18(0.34)$ & $0.19(0.34)$ \\
\hline Student-teacher ratio in primary education & & & $7.74^{* *}(2.63)$ & $8.02^{* *}(2.66)$ & $8.05^{* *}(2.66)$ & $8.35^{* *}(2.67)$ \\
\hline Highly stratified education system & & & $-11.48(11.76)$ & $15.90(13.32)$ & $14.32(13.59)$ & $14.64(13.35)$ \\
\hline Highly stratified education system * parental education & & & & $-5.77^{* *}(1.36)$ & $-5.75^{* *}(1.36)$ & $-5.76^{* *}(1.35)$ \\
\hline Moderately differentiated education system & & & $16.53(14.56)$ & $47.27^{* *}(15.98)$ & $46.64^{* *}(15.97)$ & $49.25^{* *}(16.00)$ \\
\hline Moderately differentiated education system * parental education & & & & $-6.57^{* *}(1.47)$ & $-6.55^{* *}(1.47)$ & $-6.57^{* *}(1.47)$ \\
\hline \multicolumn{7}{|l|}{ Origin effects of education } \\
\hline Compulsory years of education & & & $8.50^{* *}(1.76)$ & $6.69^{* *}(1.83)$ & $6.15^{* *}(2.32)$ & $5.29 * *(2.03)$ \\
\hline Compulsory years of education * 1.75 generation & & & & $2.78^{*}(1.40)$ & $2.83^{* *}(1.41)$ & $2.82^{* *}(1.40)$ \\
\hline Compulsory years of education * 1.5 generation & & & & $3.50^{* *}(1.50)$ & $3.53^{* *}(1.50)$ & $3.52^{* *}(1.50)$ \\
\hline Compulsory years of education * 1.25 generation & & & & $12.53^{* *}(2.17)$ & $12.56^{* *}(2.17)$ & $12.53^{* *}(2.17)$ \\
\hline \multicolumn{7}{|l|}{ Origin effects of economy \& politics } \\
\hline EDI & & & & & & $100.50(68.35)$ \\
\hline $\mathrm{HDI}$ & & & & & $20.25(41.02)$ & \\
\hline Political stability & & & & & $-2.15(4.76)$ & \\
\hline \multicolumn{7}{|l|}{ Individual effects } \\
\hline Grade & & $47.03^{* *}(1.41)$ & $46.96^{* *}(1.40)$ & $47.00^{* *}(1.40)$ & $47.01^{* *}(1.40)$ & $47.01^{* *}(1.40)$ \\
\hline Vocational type of education & & $-55.89^{* *}(2.70)$ & $-55.46^{* *}(2.70)$ & $-56.21^{* *}(2.69)$ & $-56.20^{* *}(2.69)$ & $-56.22^{* *}(2.69)$ \\
\hline Girls & & $-7.93^{* *}(1.61)$ & $-7.90^{* *}(1.62)$ & $-7.85^{* *}(1.61)$ & $-7.85^{* *}(1.61)$ & $-7.85^{* *}(1.61)$ \\
\hline Parental education & & $4.91^{* *}(0.56)$ & $4.90^{* *}(0.56)$ & $9.85^{* *}(1.18)$ & $9.84^{* *}(1.18)$ & $9.83^{* *}(1.18)$ \\
\hline Parental occupation & & $0.88^{* *}(0.06)$ & $0.87^{* *}(0.06)$ & $0.86^{* *}(0.06)$ & $0.86^{* *}(0.06)$ & $0.86^{* *}(0.06)$ \\
\hline
\end{tabular}


Table 3 Cross-classified regression of educational system characteristics of countries of origin and destination, controlled for individual characteristics, on the scientific literacy of migrant pupils; $\mathrm{Nd}=16, \mathrm{No}=\mathbf{3 5}, \mathbf{N i}=9.279$ (Continued)

\begin{tabular}{|c|c|c|c|c|c|c|}
\hline Home possessions & & $8.93^{* *}(1.06)$ & $8.87^{* *}(1.06)$ & $9.52^{* *}(1.06)$ & $8.52^{* *}(1.06)$ & $8.51^{* *}(1.06)$ \\
\hline \multicolumn{7}{|l|}{ Migrant characteristics } \\
\hline Second generation & & Ref. & Ref. & Ref. & Ref. & Ref. \\
\hline 1.75 generation & & $2.16(2.26)$ & $2.28(2.26)$ & $-24.91^{*}(13.67)$ & $-25.41^{*}(13.70)$ & $-25.40^{*}(13.67)$ \\
\hline 1.5 generation & & $-7.51^{* *}(2.57)$ & $-7.64^{* *}(2.57)$ & $-41.96^{* *}(15.03)$ & $-42.33^{* *}(15.01)$ & $-42.25^{* *}(15.03)$ \\
\hline 1.25 generation & & $-29.67^{* *}(3.82)$ & $-29.79^{* *}(3.81)$ & $-156.50^{* *}(22.31)$ & $-156.77^{* *}(22.32)$ & $-156.62^{* *}(22.31)$ \\
\hline Migrant generation unknown & & $-19.00^{* *}(4.33)$ & $-19.22^{* *}(4.33)$ & $-17.59^{* *}(4.34)$ & $-17.56^{* *}(4.34)$ & $-17.58^{* *}(4.34)$ \\
\hline One native parent & & $5.97(3.82)$ & $5.53(3.82)$ & $5.88(3.87)$ & $5.86(3.87)$ & $5.82(3.87)$ \\
\hline Language of test country spoken at home & & $16.38^{* *}(2.28)$ & $15.59^{* *}(2.28)$ & $15.08^{* *}(2.28)$ & $15.09^{* *}(2.28)$ & $15.08^{* *}(2.28)$ \\
\hline Language spoken at home unknown & & $-22.31^{* *}(2.85)$ & $-22.55^{* *}(2.85)$ & $-22.99^{* *}(2.84)$ & $-22.97^{* *}(2.84)$ & $-22.94^{* *}(2.84)$ \\
\hline \multicolumn{7}{|l|}{ Variance components ${ }^{\mathrm{a}}$} \\
\hline Destination & 722 & $426(41)$ & $150(79)$ & $159(78)$ & $157(78)$ & $166(77)$ \\
\hline Origin & 1926 & $715(63)$ & $505(74)$ & $498(74)$ & $494(75)$ & $473(75)$ \\
\hline Individual & 6766 & $5476(42)$ & $5479(42)$ & $5479(42)$ & $5480(42)$ & $5480(42)$ \\
\hline Measurement model & 0.36 & 0.05 & 0.04 & 0.02 & 0.02 & 0.02 \\
\hline Deviance (IGLS; -2*LL) & 109690 & 107175 & 107145 & 107089 & 107089 & 107087 \\
\hline
\end{tabular}

Source: PISA 2006, own calculations. Notes: standard deviations in parentheses; ${ }^{* *}=$ significant at the 0.05 level, ${ }^{*}=$ significant at the 0.1 level. ${ }^{a}$ Between parentheses, the explained variance (in $\left.\%\right)$ at respectively
destination, origin, and individual level, as compared to model 0 (Table 3). As recommended by Snijders and Bosker (1999), the explained variance at the individual level is computed by calculating the change in total variance. 
differences in scholastic ability and in curriculum offered to the pupils. By controlling for grades, cross-national differences in grading cannot explain the found effects of characteristics of educational systems.

The results furthermore underscore the importance of taking into account migrant children's age of migration. Second generation migrants and 1.75 generation migrants have the highest educational performance, 1.5 generation migrants score 8 points lower, and 1.25 generation migrants score 30 points lower. These results indicate that the more time migrant children have spent in their host country's educational system, the better they perform.

As can be seen from comparing the variance components of model 1 (Table 3 ) to the mentioned components of the empty model, composition effects indeed explain an important share of the initial variance in scientific performance. After inclusion of individual-level characteristics and the average performance of the natives of the destination countries, the initial variance at the destination level is reduced by $42 \%$ and the variance at the origin level by $63 \%$. Apparently, a substantial share of the differences in educational achievement across different origin groups and across migrants living in different destination countries can be attributed to differences in individual background characteristics of these groups and to the overall educational performance in their destination countries. This finding underscores the importance of individual features for explaining macro-level differences. The average educational performance of natives in the destination countries affects the performance of the migrant children positively, which reflects a general effect of the general quality of educational systems on outcomes. The results are not substantially different if we use reading or math scores instead of science scores as indicator of educational performancel.

\section{The effect of educational systems}

Due to the relatively large number of educational system characteristics in comparison to the rather limited degrees of freedom at the destination and partly at the origin level, we have added all macro-characteristics at the destination and origin levels separately one by one to model 1 of Table 3. The parameters of these additions are shown in Table 4. Subsequently, the significant educational system characteristics have been added step for step simultaneously to model 1 of Table 3, starting with the characteristics that resulted in the largest improvement in model fit in Table 4. In model 2 of Table 3, only the significant educational system features of origin and destination countries are presented. In model 3, the hypothesized cross-level interactions are added ${ }^{\mathrm{m}}$.

At the destination level, the degree of differentiation of an educational system significantly affects migrant children's educational performance. The educational performance of migrant children in highly stratified educational systems is 16 points higher than the performance of their counterparts in comprehensive systems, although this difference is not significant. This finding supports partly hypothesis 1 . But the effect of moderately differentiated education system on education performance is more positive (although not significant) than that of a comprehensive education system (16 points), and that runs partly against the first hypothesis that any differentiation in educational systems is detrimental for the educational performance of migrant children. The inclusion of cross-level interactions between the degree of differentiation and parental background (model 3) reveals some interesting additional 
Table 4 The coefficients, standard errors and improvement in model fit in a single addition of the origin and destination educational characteristics to model 1 of Table 3, relative to the performance of the natives in the countries of destination

\begin{tabular}{|c|c|c|c|c|}
\hline & & Co. & SE & IMF \\
\hline \multicolumn{5}{|c|}{ Destination effects } \\
\hline \multirow[t]{3}{*}{ Resources } & Quality educational resources & -7.44 & 19.95 & 1 \\
\hline & Degree of teacher shortage & 0.94 & 13.99 & 0 \\
\hline & Student-teacher ratio in primary education & $6.41^{* *}$ & 2.70 & 1 \\
\hline Standardization & Nationally standardized exams science & -3.32 & 14.40 & 1 \\
\hline \multirow[t]{4}{*}{ Differentiation } & Highly stratified system & -24.53 & 13.99 & 3 \\
\hline & Moderately differentiated system & -1.57 & 15.81 & 3 \\
\hline & Highly stratified system * parental education & $-5.62^{* *}$ & 1.36 & 14 \\
\hline & Moderately differentiated system * parental education & $-6.19^{* *}$ & 1.48 & 14 \\
\hline \multicolumn{5}{|l|}{ Origin effects } \\
\hline \multirow[t]{8}{*}{ Resources } & EDI-score & $202.29^{* *}$ & 66.56 & 9 \\
\hline & EDI-score * 1.25 generation & 112.15 & 76.71 & 13 \\
\hline & EDI-score ${ }^{*} 1.5$ generation & 62.63 & 58.85 & 13 \\
\hline & EDI-score * 1.75 generation & -30.69 & 50.84 & 13 \\
\hline & Student-teacher ratio in primary education & $-1.33^{* *}$ & 0.45 & 9 \\
\hline & Student-teacher ratio in primary education * 1.25 generation & -0.27 & 0.51 & 9 \\
\hline & Student-teacher ratio in primary education * 1.5 generation & -0.18 & 0.33 & 9 \\
\hline & Student-teacher ratio in primary education * 1.75 generation & 0.13 & 0.82 & 9 \\
\hline \multirow[t]{4}{*}{ Standardization } & Compulsory years of education & $8.84^{* *}$ & 1.82 & 20 \\
\hline & Compulsory years of education * 1.25 generation & $12.35^{* *}$ & 2.17 & 53 \\
\hline & Compulsory years of education * 1.5 generation & $3.44^{* *}$ & 1.50 & 53 \\
\hline & Compulsory years of education * 1.75 generation & $2.80^{* *}$ & 1.40 & 53 \\
\hline
\end{tabular}

Source: PISA 2006, own calculations.

Note: ${ }^{* *}=$ significant at the 0.05 level, ${ }^{*}=$ significant at the 0.1 level.

information. Whereas former research has repeatedly shown that the effect of social class origin on the educational performance of native pupils is larger in countries with differentiated educational systems (see e.g. Dupriez et al., 2008; Duru-Bellat and Suchaut, 2005; Pfeffer, 2008; and Schütz, Ursprung, and Wössmann, 2005), we find the opposite pattern for migrant pupils. Figure 1 illustrates this interaction: the influence of parental education on the educational performance of migrants is weaker in

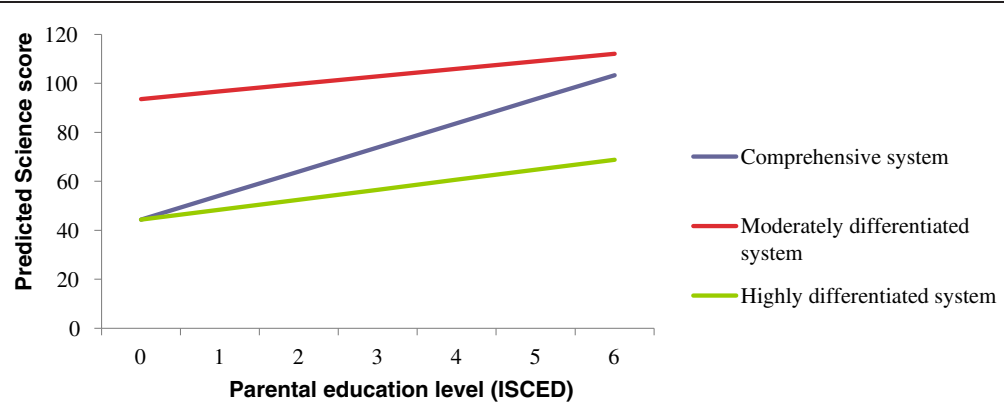

Figure 1 The average science score of migrant children by parental education and the degree of differentiation of the destination countries' educational systems (based on model 3, Table 4). 
highly and moderately differentiated education systems than in comprehensive systems. Stated differently, no matter how well migrants' parents are educated, their performance is lowest in highly stratified systems, and the highest in moderately differentiated systems.

This outcome cannot be explained by the inclusion of grade of the pupil or the vocational education, which a pupil might attend. If we exclude grade and/or vocational education, the main effects of highly or moderately differentiated systems remain positive (although not significant), and the effect of parental education of migrant pupils remain less strong in highly or moderately differentiated systems (see Table 5).

No support has been lent to hypothesis $2 \mathrm{~A}$ on the importance of external standards. The existence of nationally standardized examinations in science has no significant influence on migrant pupils' performance. Hypothesis $3 \mathrm{~A}$ on the resources of a destination country's educational system does not receive any support from our findings. As can be seen in model 2, the educational performance of migrants is higher in countries with higher student-teacher ration in primary education. In additional analysis we added the GDP of the destination countries to the equation (model 3). This inclusion of GDP at the destination level had hardly an effect on the coefficients ${ }^{\mathrm{n}}$.

At the origin level, the duration of compulsory education has a substantial positive influence on scientific performance $(b=8.50$; model 2$)$. In line with hypothesis $2 \mathrm{~B}$, this positive influence is strongest for migrant children who attended part of their education in their origin country (the 1.25 generation, and to a lesser extent, the 1.5 generation). Figure 2 graphically displays this interaction. Whereas the difference in educational performance between second generation migrants who originate from countries with 5 or 13 years of compulsory education is 54 score points, the difference for the 1.75 generation is 76 points, for the 1.5 generation 82 points, and for the 1.25 generation no less than 154 points.

In order to rule out the possibility that years of compulsory education are a mere reflection of origin countries' level of economic and political prosperity, we add both origin countries' scores on political stability and economic prosperity (HDI). Model 4 of Table 3 shows that those indicators did not significantly influence migrants' educational performance and their inclusion affected the other coefficients hardly. The significant effect of the EDI-score at the origin level (in Table 4) turned insignificant in combination with other variables, like compulsory years, as shown in model 5 of Table 3. Hypothesis 3B has to be rejected. However, if we run analyses without years of compulsory education but with the two indicators of political stability and economic prosperity, the effect of HDI is positive and becomes significant while the effect of political stability remains negative but still insignificant ${ }^{\circ}$.

The variance in scientific performance at the destination level has declined by $78 \%$ after addition of the educational system characteristics and the cross-level interactions in model 3. The variance at the origin level has been reduced by $74 \%$.

\section{Conclusion and discussion}

The focus of this study was on educational system features of origin and destination countries and their relation with the educational performance of 15-years old migrant children. Relying on the literature on educational systems, we assumed that educational systems broadly differ in their degree of differentiation, their level of standardization, 
Table 5 Cross-classified regressions of educational system characteristics of countries of origin and destination, controlled for individual characteristics (model 3 ) on the science score, but without grade and/or vocational type of education as individual controls

\begin{tabular}{|c|c|c|c|}
\hline & -Grade & -Vocational & $\begin{array}{l}\text {-Grade \& } \\
\text {-Vocational }\end{array}$ \\
\hline Intercept & $115.75(144.25)$ & $182.83(123.04)$ & $189.26(129.26)$ \\
\hline \multicolumn{4}{|l|}{ Destination effects of education } \\
\hline Average educational performance natives & $0.14(0.31)$ & $0.06(0.27)$ & $0.06(0.28)$ \\
\hline Student-teacher ratio primary education & $7.66^{* *}(2.29)$ & $8.62^{* *}(1.85)$ & $8.16^{* *}(1.94)$ \\
\hline Highly stratified education system & $7.57(12.11)$ & $10.68(10.46)$ & $5.53(10.95)$ \\
\hline Highly stratified system * parental education & $-4.14^{* *}(1.43)$ & $-5.89 * *(1.34)$ & $-4.36^{* *}(1.44)$ \\
\hline Moderately differentiated system & $32.71 * *(14.56)$ & $28.81^{* *}(12.52)$ & $22.82(13.12)$ \\
\hline Moderately differentiated system * parental education & $-4.51^{* *}(1.56)$ & $-5.70^{* *}(1.50)$ & $-4.12^{* *}(1.57)$ \\
\hline \multicolumn{4}{|l|}{ Origin effects of education } \\
\hline Compulsory years of education & $6.21^{* *}(1.92)$ & $6.30^{* *}(1.80)$ & $5.97^{* *}(1.89)$ \\
\hline Compulsory years of education * 1.75 generation & $3.72^{* *}(1.48)$ & $2.55(1.43)$ & $3.49^{* *}(1.49)$ \\
\hline Compulsory years of education * 1.5 generation & $6.11 * *(1.58)$ & $3.20^{* *}(1.53)$ & $5.68^{* *}(1.59)$ \\
\hline Compulsory years of education * 1.25 generation & $14.14^{* *}(2.30)$ & $10.94(2.31)$ & $12.97^{* *}(2.31)$ \\
\hline \multicolumn{4}{|l|}{ Individual effects } \\
\hline Grade & $x$ & $40.04^{* *}(1.40)$ & $x$ \\
\hline Vocational type of education & $-34.27^{* *}(2.75)$ & $x$ & $x$ \\
\hline Girls & $-3.35^{*}(1.70)$ & $-6.15^{* *}(1.64)$ & $-2.69(1.71)$ \\
\hline Parental education & $9.34^{* *}(1.25)$ & $10.06^{* *}(1.21)$ & $9.51^{* *}(1.26)$ \\
\hline Parental occupation & $1.05^{* *}(0.06)$ & $0.96^{* *}(0.06)$ & $1.10^{* *}(0.06)$ \\
\hline Home possessions & $11.94^{* *}(1.11)$ & $9.78^{* *}(1.08)$ & $12.42^{* *}(1.12)$ \\
\hline \multicolumn{4}{|l|}{ Migrant characteristics } \\
\hline Second generation & Ref. & Ref. & Ref. \\
\hline 1.75 generation & $-33.43^{* *}(14.45)$ & $-22.31(13.97)$ & $-31.07^{* *}(14.56)$ \\
\hline 1.5 generation & $-74.63^{* *}(15.86)$ & $-39.34^{* *}(15.36)$ & $-69.95^{* *}(15.98)$ \\
\hline 1.25 generation & $-180.83^{* *}(23.59)$ & $-139.41^{* *}(22.81)$ & $-167.67^{* *}(23.76)$ \\
\hline Migrant generation unknown & $-20.85^{* *}(4.59)$ & $-18.11(4.44)$ & $-20.84^{* *}(4.63)$ \\
\hline One native parent & $3.70(4.10)$ & $7.53(3.96)$ & $4.99(4.13)$ \\
\hline Language of test country spoken at home & $16.35^{* *}(2.41)$ & $14.67^{* *}(2.33)$ & $15.96^{* *}(2.43)$ \\
\hline Language spoken at home unknown & $-27.83^{* *}(3.01)$ & $-24.16^{* *}(2.91)$ & $-28.09 * *(3.03)$ \\
\hline \multicolumn{4}{|l|}{ Variance components ${ }^{\mathrm{a}}$} \\
\hline Destination & $56(74)$ & $0(0)$ & $0(0)$ \\
\hline Origin & $567(124)$ & $502(106)$ & $555(111)$ \\
\hline Individual & $6113(224)$ & 5766 & $6224(228)$ \\
\hline Measurement model & 0.03 & 0.02 & 0.04 \\
\hline Deviance (IGLS; -2*LL) & 108146 & 107509 & 108297 \\
\hline
\end{tabular}

Source: PISA 2006, own calculations. Notes: standard deviations in parentheses; ${ }^{* *}=$ significant at the 0.05 level, $*$ significant at the 0.1 level.

and the availability of resources and that these system features are significant for the educational performance of migrant children. Using PISA 2006 data, this research has examined the scientific performance of 9.279 migrant pupils from 35 different countries of origin living in 16 different Western countries of destination. Although former and also our research underscore the importance of individual in explaining migrant 


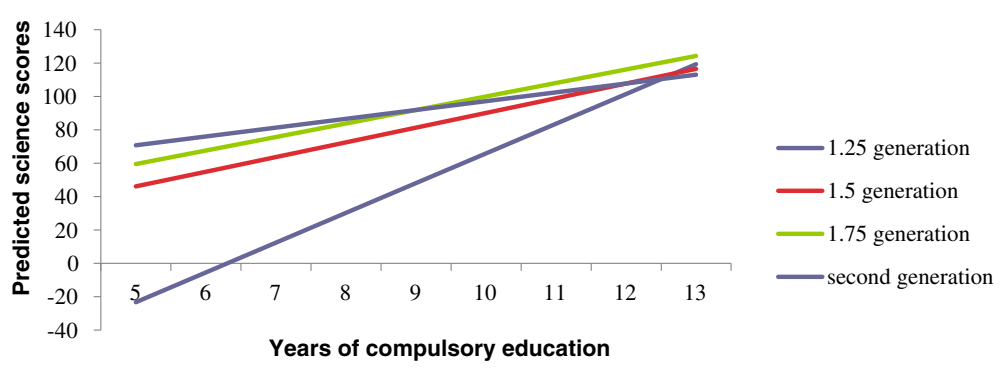

Figure $\mathbf{2}$ The average science score of migrant children by migrant generation and the compulsory years of education in the countries of origin (based on model 3, Table 4).

children's educational performance (Levels et al., 2008) we show that the features of the educational systems of both origin and destination countries also affect the educational performance of migrant children, independently of the economic and political prosperity of the origin countries, the average educational performance of the natives in the destination countries or the GDP of destination countries. As said earlier, the results with reading or math scores as dependent variables instead of scientific literacy are substantially the same, which is additional evidence that characteristics of educational systems are relevant for educational outcomes.

Our analysis reveals also that differences in average scientific performance across migrants living in different destination countries cannot be solely attributed to compositional differences of the migrants or the average educational performance of the natives in the countries of destination. The degree to which an educational system is highly stratified has an important influence on migrant children's educational performance. In contrast with our expectations, the science performance of migrant pupils with low educated parents is in highly stratified educational systems equal to comparable pupils in educational systems without differentiation, but the science performance of migrant pupils with higher educated parents is lower in highly stratified systems. In highly stratified systems, pupils have to choose between different educational tracks at a relatively young age. As a result of their lower linguistic resources and the lower parental knowledge of the educational options migrant pupils in highly stratified systems are more likely to be selected into lower school-types, in which they have a less demanding curriculum and a less favorable school composition, than comparable migrant pupils in less differentiated systems. Interestingly, our results indicate that the science score of migrant children with low educated parents is highest in moderately differentiated systems, and not in comprehensive systems. But migrant pupils with high-educated parents perform lowest in highly stratified educational systems compared with migrant pupils from the same social class in moderately differentiated or comprehensive systems. So, the highly stratified educational system seems even not to function as a good sorting system for well performing migrant children from the higher social classes. The combination of these findings suggest that the educational performance of the average migrant pupils is only hampered in highly stratified systems, but not in moderately differentiated systems. The latter conclusion deviates from results found by Pfeffer (2008) and Dunne (2010) for native pupils from lower classes, who perform also less in differentiated educational systems (see also Dronkers, Van der Velde \& Dunne, 2012). 
In addition to the negative effect of differentiation, our results show that migrant pupils perform better in destination countries that have a higher student-teacher ratio, also with control for the average score of the native pupils. This result might be unexpected, but a possible explanation is that smaller classes in primary education imply less well-paid teachers (an euro or dollar can be spent only once) and thus less unqualified teachers. Migrant pupils might be more vulnerable for a lower quality of teaching due to their lack of linguistic resources and their lower knowledge of their country of destination. The strong effect of attending vocational track on educational performance of comparable migrant pupils is another indication of the importance of early curriculum differentiation. Vocational schools pay more attention to practical skills needed at the labor market, while general education focus on more abstract knowledge, related to later entrance of college or university. This different curriculum offered in vocational and general education leads to different educational performance of the pupils. The negative effect of stratified educational systems on the educational performance of migrant children cannot be explained by the existence of a vocational stream within these systems. Our results show that both features have independent negative effects on educational performance of comparable migrant children.

Also the grade of the pupil has a strong effect on performance. This effect might both reflect differences in scholastic performance in primary and early secondary education and differences in offered curriculum. The negative effect of stratified educational systems on the educational performance of migrant children cannot be explained by the existence of differences in grading in these educational systems.

We did not find the hypothesized effect of the national examination in destination countries on migrant children outcome. It might be that a national exam also compels schools to be cautious with the placement of pupils, who might have a higher propensity to fail the national exam. Migrant children might be considered by school authorities to be such a risk and therefore placed in a lower track.

As was the case at the destination level, differences in scientific literacy across migrants originating from different countries of origin cannot be solely attributed to compositional differences or to the average educational performances in their countries of destination. The years of compulsory education in the origin country caused a substantial reduction in variance at the origin level: the longer the length of compulsory education, the better especially first generation migrant children who have attended education in that particular origin country perform in science. Our models show that compulsory years of education are not a mere reflection of origin countries' level of economic or political prosperity (more developed and stable nations attach a higher value to education, and therefore make standardized education compulsory for a longer length of time). The length of compulsory education might be an independent indicator of quality of education offered to all pupils in migrants' origin countries. The positive effect of duration of compulsory education for migrant children who never attended education in their origin country (the second and 1.75 generation), can most likely be attributed to unmeasured parental educational resources. This unmeasured variance is likely to be related to the length of standardized compulsory education in the countries of origin, which might be an indicator of the quality of education for all pupils in their origin country.

Overall, this study has underscored the importance of taking into account educational system features as an explanation of differences in educational achievement 
across different origin groups and across migrants living in different destination countries. Although individual level characteristics account for the largest educational achievement differences between migrant pupils, educational system characteristics have an effect on top of these individual level characteristics and the average educational performance in their countries of origin. We also showed that differences in educational systems contribute to explaining the effects of economic and political macro-characteristics of the countries of origin (HDI, Political stability) on the educational performance of migrant children in destination countries. This means that the effects of educational system features partly intermediate the effects of economic development.

Our results improve those of Levels et al (2008) by showing that both features of the educational systems and the level of economic and political prosperity of origin countries should be included while analyzing educational performance of migrant children. Our results suggest that the level of economic and political prosperity of the origin countries influences the features of the educational system of origin, but that this prosperity has only an indirect effect on outcomes via the standardized quality of the educational system, measured by length of compulsory education. Levels et al (2008) have overestimated the effect of economic and political development, because they did not include educational system features in their analysis ${ }^{\mathrm{p}}$.

The finding that the educational performance of migrant pupils is partly determined by characteristics of educational structure of their countries of origin and destination, calls for more direct measures of various aspects countries' educational systems and the inclusion of other aspects of educational systems in further analyses. We consider this article only as a start of such an endeavor. Moreover, in order to provide more robust tests of hypotheses concerning effects of educational systems, information from a larger number of destination countries would be necessary. Given the importance of migrant children success in education, it is incomprehensible that OECD destination countries like Canada, France, United Kingdom, United States or Sweden do not collect and make available this information ${ }^{\mathrm{q}}$.

We wish to reiterate that with cross-sectional data, we can only establish associations or relationships between variables, but cannot rule out whether this association is not caused by another unmeasured variable. Here we are at the limits of cross-sectional international data.

Another important improvement will be the inclusion of a school-level between the levels of counties of origin and destination and the individual pupil. Dunne (2010) and Dronkers and Van der Velde (2013) showed independently that school characteristics like school composition and ethnic and social-cultural diversity in schools have different effects and implications in different educational systems for educational achievement, although these school-level variables seem not explain away the independent effects of origin and destination macro-characteristics (see also Dronkers, Van der Velde \& Dunne, 2012).

\section{Endnotes}

${ }^{a}$ This does not mean that more informal tracking or streaming does not exist within the schools in countries with comprehensive systems, especially in relation to subjects as math or science. But the PISA data do not allow their revelation in a systematic way. 
${ }^{\mathrm{b}}$ Other forms of external standards like national assessment or a national inspectorate are less reliable indicators for a cross-national analysis.

${ }^{c}$ However, if we use the more limited measurement of reading and mathematics in PISA 2006 as dependent variables, our results are substantially the same.

${ }^{\mathrm{d}}$ Information on the construction of the origin of the pupils and the number of migrants in each combination is available on the webpage of the (Additional file 1: Table S1 and Table S2).

${ }^{\mathrm{e}}$ By excluding countries with less than in total 30 cases, we want to avoid the danger of country of destination outliers based on a low number of cases pupils. The excluded origin countries are Bangladesh (5), Czech republic (6), Denmark (15), Estonia (8), Greece (15), Hungary (12), Liechtenstein (4), Rumania (28), Slovakia (6), Slovenia (5), Macedonia (22).

${ }^{\mathrm{f}}$ Since the OECD allows participating countries to propose their own birth country categories, some countries have measured more origin countries than others. As a result, the number origin countries in the different countries of destination are partly dependent on the quality of the national survey. Therefore we have compared the origin countries in PISA with national statistics. In the case of Australia, Austria, Finland, Switzerland, Luxembourg, and New Zealand the three largest migrant groups as identified by the statistical offices are also represented in PISA data. In the case of Belgium, Germany, Liechtenstein, the Netherlands, and Scotland, the two largest groups are represented. In Greece, the largest migrant group (Albanians, Eurostat, 2008) is that also in PISA data. Russians are the largest migrant group in Latvia (Eurostat, 2008), which is also he case in PISA data.

${ }^{\mathrm{g}}$ After this selection for valid information on countries of birth, there is no respondent left with a missing value on the dependent variable.

${ }^{\mathrm{h}}$ Computation of measurement error of the dependent variable is done with this formulae: $\left[(\mathrm{MP}-\mathrm{P} 1)^{2}+(\mathrm{MP}-\mathrm{P} 2)^{2}+(\mathrm{MP}-\mathrm{P} 3)^{2}+(\mathrm{MP}-\mathrm{P} 4)^{2}+(\mathrm{MP}-\mathrm{P} 5)^{2}\right] / 5 . \mathrm{MP}=$ average 5 plausible values and $\mathrm{P} 1$ to $\mathrm{P} 5$ are the plausible values.

${ }^{\mathrm{i}}$ To our knowledge, statistical software that can combine the analyses of plausible values as outcomes with a cross-classified multilevel design does not exist. STATA Stata Corp uses Gauss-Hermite quadrature and allows for modeling cross-classified effects up to two levels. However, the ado macro that allows for analyzing plausible values (pv.ado) can work only with statistical packages that allow for using weights. The stata packages designed to analyse cross-classified data structures (xtmixed and gllamm) do not work with plausible values. SPSS-macro's for plausible values are not designed for analyzing data in a cross-classified design. Specialized multilevel software packages are also limited in this extent. The newest version of MIWin (which we use in this paper) allows for estimating cross-classified models, but cannot deal with plausible values. Two-level cross-classified random-effect models have also been implemented in HLM. In principle, the HLM7 software allows for analyzing both plausible values as outcomes and cross-classified models. However, the HLM packages that allow for crossclassified analyses (i.e. HCM2 and HCM3) do not allow for using plausible values as outcome variables.

${ }^{j}$ We have computed the models of Table 3 also without the average science performance of the natives (see Additional file 1: Table S3). The deletion of this macro-variable had hardly any effect on the coefficients in Table 3. 
${ }^{\mathrm{k}}$ The inclusion of an additional school-level does not eliminate the variance of origin or destination country (Dronkers, van der Velden and Dunne, 2012; Dronkers and van der Velden, 2013).

${ }^{1}$ See Additional file 1: Table S4.

${ }^{\mathrm{m}}$ We have conducted a number of sensitivity analyses for the results of the parameters of the countries of destination (see Additional file 1: Table S5). The first was the deletion one by one each of the countries of destination from model 3, the deletion of four destination countries with few cases or the deletion of three small countries. The parameters happen to remain stable and not substantially affected by the deletion of one or more of the countries of destination. The second sensitivity analysis used the difference on the Hofstede (1980) collectivism-individualism dimension between origin and destination country as an indicator of the cultural distance between migrants' origin and destination. The addition of this difference show that migrant children, who origin from countries with a higher collectivism score relative to their destination country, have lower educational outcomes, but the addition of this cultural distance does not alter the effects of the characteristics of the educational systems. The third sensitivity analysis was the deletion of the four largest combinations of origin and destination countries. The parameters happen to remain stable and not substantially affected by the deletion of one of these combinations of origin and destination.

${ }^{\mathrm{n}}$ See Additional file 1: Table S6.

${ }^{\circ}$ See Additional file 1: Table S6.

${ }^{\mathrm{P}}$ We have made analysis with more macro-characteristics of the countries of origin. Although we had fewer degrees of freedom due to the higher number of included macro-variables, the reported effects of the educational systems remain more or less equal and also significant.

${ }^{\mathrm{q}}$ Also in PISA wave 2009 these countries have not measured the countries of birth.

\section{Additional file}

Additional file 1: Table S1. Schematic overview of the decision rules used to determine a pupil's country of origin and migrant status. Table S2: Overview of the number of migrant pupils by country of origin and country of destination. Table S3: Cross-classified regression of educational system characteristics of countries of origin and destination on the scientific literacy of migrant pupils, not controlled for the average performance of natives in the countries of destination; $\mathrm{Nd}=16, \mathrm{No}=35, \mathrm{Ni}=9.279$. Table S4: Cross-classified regressions of educational system characteristics of countries of origin and destination, controlled for individual characteristics (model 3), on the science, reading and math score of migrant pupils. Table $\mathbf{S 5}$ : Sensitivity analysis of the macro-level effects, based on model 3 of Table S3 (individual level effects not presented). Destination countries one by one excluded, four destination countries with a unique combination their origin countries excluded (Greece, Lithuania, Norway, Portugal), without three smallest destination countries (Liechtenstein, Luxembourg, Lithuania), effects controlled for origin \& destination difference on Hofstede's (1980) collectivism-individualism dimension \& four large combinations of origin \& destination (Serbia in Switzerland; Portuguese in Luxembourg; Turks in Netherlands; UK in Australia). Table S6: Cross-classified regressions of educational system characteristics of countries of origin and destination, controlled for individual characteristics (model 3) on the science, but without grade and/or vocational type of education as individual controls. Table S7: Cross-classified regressions of educational system characteristics of countries of origin and destination, controlled for not shown individual characteristics (model 3) with GDP of destination country or without compulsory education but with $\mathrm{HDI}$ and Kaufman political stability (model 4). 


\section{Authors' information}

Jaap Dronkers holds the chair in 'International comparative research on educational performance and social inequality' at the Maastricht University (the Netherlands).

Mark Levels is postdoc at the Maastricht University (the Netherlands).

Manon de Heus is freelance writer and journalist.

Received: 1 June 2013 Accepted: 17 December 2013

Published: 14 January 2014

\section{References}

Ammermüller, A. (2005). Educational Opportunities and the Role of Institutions (ZEW Discussion Paper No. 05-44).

Baker, DP, \& LeTendre, G. (2005). National Differences, Global Similarities: World Culture and the Future of Schooling. Stanford: Stanford University Press.

Bankston, CL, \& Zhou, M. (2002). Being well vs. doing well: self-esteem and school performance among migrant and non-migrant racial and ethnic groups. International Migration Review, 36(2), 389-415.

Breen, R, Luijkx, R, Müller, W, \& Pollak, R. (2009). Non-persistent inequality in educational attainment: evidence from eight European countries. American Journal of Sociology, 114, 5.

Bishop, JH. (1997). The effect of national standards and curriculum-based exams on achievement. American Economic Review, 87(2), 260-264.

Brinbaum, Y, \& Cebolla-Boado. (2007). The school careers of ethnic minority youth in france: success or disillusion? Ethnicities, 7(3), 445-474.

Browne, W. (2003). MCMC Estimation in MLwiN. London: Centre for Multilevel Modelling.

Buchmann, C, \& Hannum, E. (2001). Education and Stratification in developing countries: a review of theories and empirical research. Annual Review of Sociology, 27, 77-102.

Buchmann, C, \& Parrado, E. (2006). Educational Achievement of Migrant-origin and Native Students: a comparative analysis informed by institutional theory. In DP Parker \& AW Wiseman (Eds.), The impact of comparative education research on institutional theory (pp. 345-377). Oxford: Elsevier Science.

Camburn, EM. (1990). College completion among students from high schools located in large metropolitan areas. American Journal of Education, 98, 551-569.

Coleman, JS, Campbell, EQ, Hobson, CJ, McPartland, J, Mood, AM, Weinfeld, FD, \& York, RL. (1966). Equality of Educational Opportunity. Washington DC: U.S. Department of Education.

Dronkers, J. (2010). Features of educational Systems as Factors in the Creation of Unequal Educational Outcomes. In J Dronkers (Ed.), Quality and Inequality of Education: Cross-National Perspectives (pp. 299-328). Dordrecht /Heidelberg/ London/ New York: Springer.

Dronkers, J, \& Van der Velden, R. (2013). Positive but also negative effects of ethnic diversity in schools on educational achievement? An empirical test with cross-national PISA-data. In M Windzio (Ed.), Integration and Inequality in Educational Institutions (pp. 71-98). Dordrecht, Heidelberg, London, New York: Springer.

Dronkers, J, van der Velden, R, \& Dunne, A. (2012). Why are migrant students better off in certain types of educational systems or schools than in others? European Educational Research Journal, 11, 11-44.

Dunne, A. (2010). Dividing lines: examining the relative importance of between- and within-school differentiation during lower secondary education: Ph.D. Florence: European University Institute.

Dupriez, V, Dumay, X, \& Vause, A. (2008). How do school systems manage pupils' heterogeneity? Comparative Education Review, 52(2), 245-273.

Duru-Bellat, M, \& Suchaut, B. (2005). Organization and context, efficiency and equity of educational systems: what PISA tells us. European Educational Research Journal, 4(3), 181-194.

Eurostat. (2008). Immigration in the EU27 in 2006. Available from: http://epp.eurostat.ec.europa.eu/pls/portal/docs/PAGE/ PGP_PRD_CAT_PREREL/PGE_CAT_PREREL_YEAR_2008/PGE_CAT_PREREL_YEAR_2008_MONTH_11/3-18112008-ENAP.PDF (last access: February 26, 2009).

Gamoran, A, Nystrand, M, Berends, M, \& LePorc, PC. (1995). An organisational analysis of the effects of ability grouping. American Educational Research Journal, 32, 687-715.

Ganzeboom, HBG, De Graaf, P, Treiman, DJ, \& De Leeuw, J. (1992). A standard international socioeconomic index of occupational status. Social Science Research, 21, 1-56.

Hanushek, EA, \& Wössmann, L. (2005). Does educational tracking affect performance and inequality? differences-in-differences evidence across countries. Economic Journal, 116, C63-C76.

Heath, A, \& Brinbaum, Y. (2007). Explaining ethnic inequalities in educational attainment. Ethnicities, 7(3), 291-305.

Heyneman, SP, \& Loxley, WA. (1983). The effect of primary-school quality on academic achievement across twenty-nine high- and low-income countries. The American Journal of Sociology, 88(6), 1162-1194.

Hofstede, G. (1980). Culture's Consequences: International Differences in Work Related Values. Thousand Oaks, CA: Sage Publications, Inc.

Hox, J. (2002). Multilevel Analysis: Techniques and Applications. Mahwah (NJ)/ London: Lawrence Erlbaum.

Human Development Index. United Nation Development Programme. (2007). Retrieved February 2008. (http://hdr.undp. org/en/data)

Kao, G, Tienda, M, \& Schneider, B. (1996). Racial and ethnic variation in educational achievement. Research in Sociology of Education and Socialization, 11, 263-297.

Kao, G, \& Thompson, JS. (2003). Racial and ethnic stratification in educational achievement and attainment. Annual Review of Sociology, 29, 417-442.

Kaufmann, D, Kraay, A, \& Mastruzzi, M. (2005). Governance Matters IV: Governance Indicators for 1996-2004. Washington D. C: The World Bank.

Levels, M, \& Dronkers, J. (2008). Educational performance of native and migrant children from various countries of origin. Ethnic and Racial Studies, 1-22. 
Levels, M, Dronkers, J, \& Kraaykamp, G. (2008). Migrant children's educational achievement in western countries: origin, destination, and community effects on mathematical performance. American Sociological Review, 73, 835-853.

Mare, RD. (1981). Change and stability in educational stratification. American Sociological Review, 46, 72-87.

Mare, RD. (1995). Changes in Educational Attainment and Social Enrolment. In R Farley (Ed.), State of the Union: America in the 1990s (pp. 155-213). New York: Russell Sage Foundation.

Marks, GN. (2005). Accounting for migrant non-migrant differences in reading and mathematics in twenty countries. Ethnic and Racial Studies, 28, 925-946.

Miller, LS. (1995). An American Imperative: Accelerating Minority Educational Advancement. New Haven: Yale University Press.

Organisation for Economic Co-operation and Development. (2006). Where Migrant Students Succeed: A Comparative Review of Performance and Engagement in PISA 2003. Paris: Organisation for Economic Co-operation and Development.

Pfeffer, F. (2008). Persistent inequality in educational attainment and its institutional context. European Sociological Review, 24(5), 543-565.

Phalet, K, Deboosere, P, \& Bastiaenssen, V. (2007). Old and new educational inequalities: ethnic minorities in the Belgian census 1991-2001. Ethnicities, 7(3), 390-415.

Raudenbush, SW, \& Bryk, AS. (2002). Hierarchical Linear Models: Applications and Data Analysis Methods. London: Sage.

Rumbaut, R. (2004). Ages, life stages, and generational cohorts: decomposing the migrant first and second generations in the United States. International Migration Review, 38(3), 1160-1205.

Scheerens, J, \& Bosker, R. (1997). The Foundations of Educational Effectiveness. Kidlington/New York/Toyko: Pergamon.

Schneider, SL (Ed.). (2008). The International Standard Classification of Education (ISCED-97): An Evaluation of Content and Criterion Validity for 15 European Countries. Mannheim: Mannheimer Zentrum für Europäische Sozialforschung.

Schnepf, SV, et al. (2006). How Different are Migrants? A Cross-Country and Cross-Survey Analysis of Educational Achievement. In C Parsons \& T Smeeding (Eds.), Immigration and the Transformation of Europe. Cambridge: Cambridge University Press.

Schütz, G, Ursprung, HW, \& Wössmann, L. (2005). Educational Policy and Equality of Opportunity (IZA Discussion Paper No. 1906).

Shavit, Y, \& Blossfeld, HP (Eds.). (1993). Persistent Inequality: Changing Educational Attainment in Thirteen Countries. CO, Westview Press: Boulder.

Shavit, Y, \& Müller, W (Eds.). (1998). From School to Work: A Comparative Study of Educational Qualifications and Occupational Destinations. Oxford: Clarendon Press.

Slavin, RE. (1990). Achievement effects of ability grouping in secondary schools: a best evidence synthesis. Review of Educational Research, 60(3), 471-499.

Snijders, TAB, \& Bosker, RJ. (1999). Multilevel Analysis: An Introduction to Basic and Advanced Multilevel Modeling. London: Sage.

United Nations Educational, Scientific and Cultural Organization. (2006). International Standard Classification of Education 1997. Paris: United Nations Educational, Scientific and Cultural Organization.

United Nations Educational, Scientific and Cultural Organization. (2007). World Data on Education. Geneva: UNESCO-IBE. Available from: http://www.ibe.unesco.org/countries/WDE/2006/index.html (last access February 20, 2009).

Van Tubergen, F. (2006). Migrant Integration: A Cross-National Study. New York: LFB Scholarly Publishing.

Van Tubergen, F, \& van de Werfhorst, H. (2007). Postimmigration investments in education: a study of migrants in the Netherlands. Demography, 44(4), 883-898.

Van de Werfhorst, HG, \& Van Tubergen, F. (2007). Ethnicity, schooling, and merit in the Netherlands. Ethnicities, 7(3), 416-444.

White, MJ, \& Kaufmann, G. (1997). Language usage, social capital, and school completion among migrants and native born ethnic groups. Social Science Quarterly, 78, 385-398.

Worbs, S. (2003). The second generation in Germany: between school and labour market. International Migration Review, 37(4), 1011-1038.

Wössmann, L. (2003). Central exit exams and student achievement: International evidence. In M West \& P Peterson (Eds.), No Child Left Behind? The politics and practice of school accountability (pp. 292-323). Washington, DC: Brookings Institution Press.

doi:10.1186/2196-0739-2-3

Cite this article as: Dronkers et al: Migrant pupils' scientific performance: the influence of educational system features of origin and destination countries. Large-scale Assessments in Education 2014 2:3.

\section{Submit your manuscript to a SpringerOpen ${ }^{\circ}$ journal and benefit from:}

- Convenient online submission

- Rigorous peer review

- Immediate publication on acceptance

- Open access: articles freely available online

- High visibility within the field

- Retaining the copyright to your article

Submit your next manuscript at $\gg$ springeropen.com 